\title{
IS THERE A RELIGIOUS FACTOR IN HEALTH CARE UTILIZATION?: A REVIEW
}

\author{
Preston L SChiller ${ }^{1}$ and Jeffrey S LeVin ${ }^{2 *}$ \\ 'RDI Research/Development/Information, 6502 106th Ave, N E. Kırkland, WA 98033 and 2Institute \\ of Gerontology, University of Michigan, 300 North Ingalls, Ann Arbor, MI 48109-2007, U S A
}

\begin{abstract}
This paper reviews more than 30 studies of health care uthization in which the effects of religion vartables are examined, an area previously unrevewed The authors found that over three-quarters of these studies reported significant religious differences in rates of utilization The most common operationalization of relıgion was religious affiliation (typically Protestant vs Catholic vs Jewish), although the effects of religious attendance and religiosity were occasionally examined Most major areas of health care use are represented in this literature, including psychiatric care, maternal and child health services, dental care, and physician and hospital utilization Despite the preponderance of significant findings, it is difficult to isolate any consistent trends, although low-order analyses seem to suggest that Jews are higher utılizers than non-Jews New findings presented from a study in Appalachia were inconclusive The authors discuss the conceptual limitations inherent in ways in which health services researchers typically investigate the effects of religion Drawing on recent work in the epidemiology of religion, several recommendations are offered regarding the prospect of future research in this area
\end{abstract}

Key words - health services research, religion, physician utılization, hospitalization, Appalalchia

\section{INTRODUCTION}

In a recent review, Levin and Schiller [1] described a large body of empirical findings lying forgotten at the margins of medical research Specifically, the authors found nearly 250 published studies dating back over 150 years which presented the results of eptdemiologic, sociomedical, and biomedical investigations into the effects of religion Nearly all of these investigations were large-scale studies in which some operationalization of religion, such as religious affiliation or religious attendance, was included as one of numerous independent variables believed to predict the rate or outcome under consideration In few of these studies, however, was it the authors' primary intention to examine the health effects of religion, the inclusion of religious indicators from the standpoint of scholarship in the area of religion and health was simply fortuitous Nevertheless, this accumulation of data yielded many important findings upon review and synthesis

Differences between religious affiliations as well as significant associations with continuous religion variables (e $\mathrm{g}$ religıous attendance, subjectıve religıosity) were found for a wide assortment of health outcomes, with respect to both morbidity and mortality These included cardiovascular disease, hypertension and stroke, uterine and other cancers, colitus and enterstis, general mortality, and overall health status The reviewers concluded that religion, generally defined, appears to exert a salutary influence Whether this

*Address correspondence to Dr J S Levin

An earlier version of this paper was presented at the Medical Sociology sessions of the Annual Meeting of the Southwestern Social Sctence Assoctation, Houston, Tex , 1985 review stımulates a renewed emphasis on religion in epidemiology or just indifference is as yet uncertain However, these significant findings in the "epıdemiology of religion" [2], coupled with findings also implicating religious effects on both mental health (see $[3,4]$ ) and general well-being (see $[5,6]$ ), ralse an important question for health services research

Specificaliy, if there is indeed an empirically verifiable relationship-or more than one such consistent association--between certain religious factors and health (and there appears to be so), then should this not manifest itself in measurable religjous differences in the uthlization of health care? More specifically, if adherence to a religious regimen has implications for health status, then should this relationship not be manifest in differential rates of physician and hospital visits (a) between the formally attached and unattached ( $1 \mathrm{e}$ between the churched and unchurched), (b) between adherents of vanous belief systems (1 e denominations) which differ in their degrees of ngor in regard to health-related demands, (c) by the extent to which fellowship is experienced ( $\mathrm{e} g$ by the frequency of religious attendance), and (d) by one's status within or commitment to one's particular religious institution (e $g$ by whether or not one is a church officer)?

This notion that health care utilization patterns might vary significantly by religious affiliation or practice has, in fact, not escaped the attention of many of the leading scholars within health services research Andersen and Newman [7] noted that religion represents a "social structure characteristic" predisposing factor which may influence patterns of health care use Mechanic [8] described how religious background plays an important role in patterns of lliness behavior Donabedian [9] commented on how religious preference may create attractions and barrı- 
ers to utılization-that due to a socioorganizational "lack of fit", services may be rendered inaccessible Several hospital reports seem to bear this out [10-12] Furthermore, information on respondents' religion has been routinely collected in large-scale health care surveys, such as those of CHAS-NORC [13], for quite some time

\section{REVIEW OF EMPIRICAL FINDINGS}

In a recent annotated bibliography of health care utilization studies, the complers claimed that "[r]eligious preference does not predict the use of health services" [14] However, in reading the precis of many of the studies cross-referenced under "religion', there seemed to be a preponderance of significant findings This brought to mind comments typical of many epidemiologists, such as, " there has been a paucity of studies examining the ep1demiological effects of religion on health "[15], made in the face of literally hundreds of positive findings With that in mind, pursuit of this review was strongly encouraged

Mindful of the expcrt comments noted earlier, we conducted a comprehensive search of the literature which, perhaps surprisingly, turned up over 30 empirical studies of health care utilization published since about 1960 in which one or more religion variables were included as independent variables in certain analyses However, as with the epidemiologic literature on religion until just recently, these studies have resisted review While this neglect may in part refiect the view of many medical and health researchers that religion is not an important or influential force in health (see [2]), this explanation fails to account for the presence of so many published findings in the first place A more likely explanation for this lack of review and synthesis may be that health services researchers are simply unaware of this body of art1cles In fact, it may be unjustified to call these articles a 'literature' Rather, the sum of these studies may represent an occasional 'guest appearance' of a religion variable in the literatures of a variety of health care utilization topics

Interestingly, aside from religious affiliation (usually operationalized as Protestant vs Catholic vs Jewish) and, on rare occasions, the frequency of religıous attendance, few other religious constructs have ever been cmployed Furthermore, where religion variables do appear, there tend to be no followup questions, important distinctions are lost by lumping many disparate groups under single headings (e g theologically liberal Congregationahsts and charismatic members of fundamentalist sects would both have to be coded as 'Protestant' in the absence of more specific categories), and it is usually left unstated exactly why such data are even collected in the first place In some cases, such information may have been gathered solely for methodological reasonsthat is, as a way of determining the distribution of respondents by denomination or of insuring the homogeneity of particular subgroups of a study ( $\mathrm{e} g$ $[16,17])$ In the remainder of these studies, however. the reason for the inclusion of religion variables is much more difficult to ascertain Rarely are other such studies cited as justification Perhaps, then, as with the epidemiologic literature, investigators are simply unaware that a large body of previously published religion-and-health data exists

In Table 1, a brief summary of these findings is presented It is interesting to note that the effects of religious factors have been examıned in most major areas of health care utilization These include the utilization of physicians, primary care, dentists, maternal and child health care, family planning services, pediatric care, psychiatric care, ambulatory care, hospital services, preventive services, health care systems, medications, and extended care As Table 1 indicates, only a handful of these studies has farled to turn up evidence of significant religious effects Nearly all of these studies have revealed that the utilization of health care varies significantly by patterns of religious affiliation or practice These studies will now be examined in greater detall

The earhest study to directly examine the effects of religion on health care utilization appears to be the seminal investigation by Johnson and his associates [18] on the determinants of oral polio vaccine (OPV) acceptance in Flonda Data on religious affiliation were crosstabulated with information on ethnicity and social class, and, overall, Catholics were found to have a lower rate of OPV acceptance than both Jews and Protestants Black Protestants also had a lower rate than Jews Interestingly, this pioneering study both avoided zero-order analysis and attended to the need to control for the potentially confounding effects of race and class, something much of the subsequent research in this area has overlooked This emphasis on communicable diseases was also seen in two early reports of participation rates in tuberculosis testing programs One study found no significant denominational differences [19], while a second did [20] In this latter study, the likelihood of grantıng permission for children to receive a TB test was greatest among Jews, followed by Protestants, Catholics, and others

Another early emphasis in this literature was on psychiatric care utilization The first study in this area was the seminal Midtown Manhattan investigation [21], in which the authors examined denominational differences in the use of psychiatric care at several sites At private hospitals and in outpatient departments. the utilization rates of Jews exceeded those of Prostestants and Catholics, while, at public hospitals, Catholics were the highest users and Jews the lowest Subsequent studies of psychiatric care utilization of student clinics found higher rates among Jews [22, 23], infrequent religious attenders $[23,24]$, and subjects with nonrehgious friends [24]

The utilization of a vaniety of maternal and child health services has also been evaluated for religious differences Jewish parents were found to be most likely to seek medical or dental care for their children on referral from a school health program, as were parents who were infrequent religıous attenders [25] In addition, a recent study of pediatric acute care found higher rates of utilization among children of Catholic, Jewish, and highly religious mothers [26] However, no differences were found by mother's affiliation in children's use of prepaid group practice care [27] Among Blacks, Catholics were more likely than Protestants to use family planning scrvices in the 


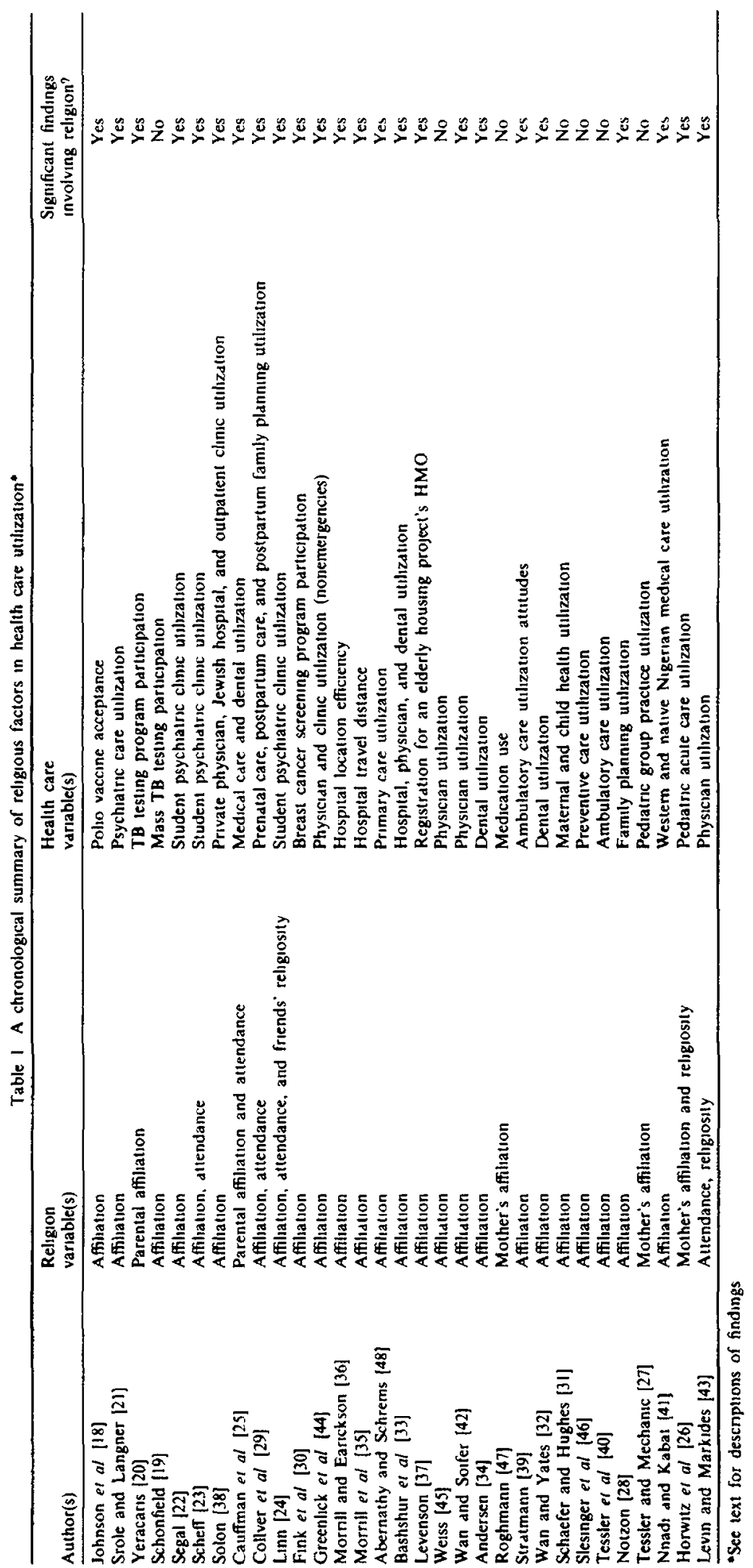


past 5 years [28], although. after delıvery, Protestants were more likely to utilize these services than Catholics [29] Infrequent religious attenders were greater users of postpartum family planning services, and, among frequent attenders, Protestants exceeded Catholics in prenatal care use [29] A study of participation in a breast cancer screening program found greater particıpation among Jews than Catholics [30] Finally, there has been one report of negative findings for rehigious differences in MCH utılization [31]

Studies of religious differences in dental utilization show consistently higher rates among Jews This has been found in an analysis at the household level [32], in a study of the propensity to travel long distances to receive care [33], and in a study controlling for a variety of other related factors [34]

A large group of studies has examined religious differences in hospital, health program, or health sys tem utllzation Jews were more likely than Catholics who were more likely than Protestants to travel great distances to reach hospitals $[33,35]$ This may be because Jews and Catholics tend to evaluate the distance to non-Jewish and non-Catholic hospitals, respectively, as being much farther away than they are in actuality [36] Jews were also found to be most likely to register for an elderly housing project's health maintenance organization [37] and to use outpatient clinics and Jewısh hospitals [38] Jews also rated economic criteria lowest in importance in determining the use of ambulatory care [39], although there do not appear to be significant affiliational differences in actual rates of use [40] Finally, in a Nigerian study [41], Muslıms were most likely to use both Western and native medicine, followed by Christians and adherents to more indigenous forms of worship

Another large group of health services studies of religıous effects has examined physician utilization The highest rates of utilization have been found in Jews $[38,42]$ and, among older people, in the highly religious [43] Studies of Protestant-Catholic differences are inconclusive, with findings dependent upon the type of medical problem responsible for utılization [44] Negative findings have been reported for affiliational differences in physician use, both in general [45] and for primary-preventıve visits [46] There are also negative findings for religious differences in medication complance [47] Finally, one study found that only among Buddhists and members of Christian sects (Mennonites, Seventhday Adventists, Christian Scientists) was the use of primary care predicted by income, age, and residency duration [48]

In sum, despite this preponderance of significant findings, it is extremely difficult to isolate in this grabbag of studies a single, generalizable conclusion about how religion and the use of health care are related Perhaps the only semi-consistent finding here is that Jews tend to use certain forms of health care more frequently than Gentiles This would certainly conform to popular or folk belief On the other hand. in most of the studies reviewed here, rarely were the effects of potentially mediating or effect-modifying factors controlled, and, further, the measurement of religion was typically unsophisticated As with the epidemiologic literature on religion, even a consis- tently sıgnificant religious effect can be difficult to interpret in the face of serious epistemological, analytical, and measurement-related problems [2] In the case of health care utılization, we hypothesized earlier that one might expect religious effects to manifest as significantly different rates of health care use by church membership status, religıous affiliation. religious attendance. and holding a church office For the most part, however, these studies have neither conceptualized nor operationalized religion in ways such that answers here may be forthcoming

Such criticism, of course, should not be overstated. as it must be kept in mind that few of these studies were designed primarily to determine the effects of religion on health care utilization Nevertheless, just because most of these studies were not specifically intended to investigate the effects of religion, this does not imply that there are not demonstrably more meaningful and fruitful approaches to measuring the effects of religion in the sociomedical sciences Levin and Vanderpool [2] recently provided a primer on investigating independent religious effects for social epidemiologists, and a couple of the issues they raised are directly applicable to studies in health services research

First, to the extent to which it can be characterized at all, religion is best conceived as a multidimensional phenomenon, or, better, a metaphenomenon That is, religion should be thought of by social epidemiologists and health services researchers as not just another construct - co-equal to, say, social support, type $\mathrm{A}$, hardiness, or occupational mobility-or even as a set of related constructs-such as access, stress, or well-being - to be plugged into causal models as if some sort of amorphous 'religion' existed as a Platonic form or a latent, higher-order, underlyıng variable Rather, religion constitutes more a domain of investigation-such as history or sociology Rehigion variables can be constructed, then, to tap either collectively or individually expenenced phenomena, and at the latter level can address beliefs, attitudes, values, behaviors, subjective experiences, thoughts. etc, each of which may interrelate with the others in a complex and perhaps undecipherable maze of assocrations which themselves may vary by religious or religioethnic identification

For example, an item inquiring about the frequency of religious attendance may not necessarily measure some innate 'relıgıosity' or religıous commitment, but, instead, might in actuality tap a combination of influences including social support, functional health, socioeconomic status, and any manner of psychodynamic motivations $[2,49,50]$ Furthermore, this nexus of phenomena rendering religious attendance a proxy indicator might vary between Jews and Gentıles, between Catholics and Protestants, or between different types of Protestants, whether divided theologically (e g liberals vs conservative evangelicals), experientially (e g mainstream vs chansmatıcs), denominationally (e $g$ Assemblies of God vs Lutherans), or withın denomınations (e g Natıonal Baptist Convention of America vs Southern Baptist Convention) Catholics, too, may exhibit healthrelated differences on the basis of ethnicity (e $\mathrm{g}$ Irısh vs Italian Catholics), as in the seminal work of Zborowskı [51] and Zola [52] These possibly 
cultural differences may also be reflected in differing motıvations for attending religious services regularly

This last point may be moot here, though, as relatively few health care utılization studies have examined the effects of religious attendance, which, in health studies of any type, is usually not measured on a broad contınuous scale Furthermore, as mentioned, the conventional measures of other aspects of religion used in these studies may serve to obscure rather than highlight religlous effects [53] Needless to say, more substantive theorizing on the nature of a significant rehgious effect ( $\mathrm{e}$ would it represent a wholly 'secular' influence or would it suggest the operation of some sort of transcendental effect?) has not yet occurred in any of the fields in which religious factors have been empirically examined-social epidemiology, health services research, and social gerontology But, then, such questions are outside of the domain of social science, as it is typically conceived

Second, as Levin and Vanderpool [2] suggest, meanıngful associations between a health-related outcome and a religion variable can obtain only if the religious indicator taps a construct or experience or phenomenon which is shared by the entirety of the population, sample, or subsample under investigation For example, an investugator should not assume that, say, religlous attendance is equally meaningful a variable for all or most subjects in the same way as age or self-rated health or socioeconomic status That is, while the subjective or symbolic value of these indicators may vary somewhat in certain circumstances, everyone, it seems, has these (an age, a health status, a social-class standing). regardless of how they score For religion variables, however, a particular concept common to certain religions may not even 'exist' within the emic framcwork of other religions ( $\mathrm{e} \mathrm{g}$ an item on the frequency of glossolalia used as an indicator of rehgious commitment in a sample of Jews and Bahats) Or, as in the case of religious attendance, a concept may indeed 'exist' in most religions yet be imbued with such drastically divergent meaning across religıous subgroups as to be of questionable value as an indicator of any higher-order construct, whether 'religiosity' or anything else

For example, a common scale measuring the frequency of attendance at religious services for use with Roman Catholics (among whom weekly attendance is required of regular communicants) and SecularHumanistic Jews (a new movement in which many Jewish holidays are not even celebrated, and those that are have been completely desacrahized) - much less with Zen Buddhists or members of Holiness sects or devotees of the Shango religion-clearly would be of questionable validity It would be extremely difficult-perhaps impossible-to extract meaning from associations with religious attendance when the scale of this variable and thus the meaning of the actual scores seem to be so variant across groups of subjects

Aside from issues related to measuring religious practice or commitment, an entirely separate set of problems arises in interpreting health- or health-carerelated differences across groups separated by re- ligious identification For example, Seventh-day Adventists and Mormons are at extremely low risk of morbidity and mortality almost across the board relative to other religious groups However, these groups are characterized by behaviorally strict health-related life styles, by higher-than-average rates of intermarnage, by strong social support networks, by belief systems and theologies fostering high degrees of personal responsibility, by many avenues, such as fellowship, services, and commons aims, which provide for the easing of tension and dread and which otherwise offer psychodynamic release, and. by fatth in God's blessing of an observant people

Religious affiliation, then, masks, or, rather, constitutes, an array of characteristics, functions, and processes which are known to be associated with health health-related behavior, heredity, social support, internal locus of control, stress-buffering, and positive mental attitude, among others [49] In socialscientific terms, each of these factors must be "controlled for' or otherwise modeled hefore we can ever understand the nature of significant religious differences, much less attribute them to superempirical or 'supernatural' mechanisms or pathways Of course, not many social scientists are likely to make this latter attribution, yet, as Levin and Markides [50] note, many casually tend to attribute such effects to social support almost by default without realizing that other explanations are possible

While there is no easy resolution for all of these 1ssues, health services researchers interested in exploring the effects of religion can take several relatively painless steps which may help to mitigate the problems encountered in previous studies First, since, as discussed, uncontrolled analyses of religion are not particularly useful for drawing conclusions regarding the presence of significant religious effects, the pertinent aspects of religion should be differentiated and modeled alongside of other determinants of health care utilization Second, where the investıgator has minımal exposure to the study and/or measurement of religious phenomena, it would be wise to consult with sociologists or psychologists of religion, or with scholars in the fields of religious studies Health services reserch seems to have met with dimınıshing returns from contınuing to 'wing it' in this regard Third, researchers should forge through their trepidation over the apparently marginal status of religion in health-related research or over the appearance to the uninitiated that some sort of implicitly mystical or 'supernatural' hypothesis drives their work While such ideas are well worth investigating, imputing to significant effects for rehigion variables an explanation founded solely in such otherworldly mechanisms is a form of reductionism not even encountered in arcane mystical texts Finally, researchers should recognize that, far from there being a dearth of religion research in health, a literature of hundreds of empirical studies exists in epidemiology, health services research, gerontology, biomedicıne, and behavioral science These studies need to be exhumed and mined for consistent findings which might suggest hypotheses for future research In this regard, religion should be treated no differently than any other domain of independent variables 


\section{NEW FINDINGS FROM APPALACHIA}

To follow up on this intriguing body of findings and better attend to the operational issues just raised, we present some additional results using data collected as a part of an evaluation of a self-care health education project implemented in an impoverished coal-mining region of Appalachia Nearly 1000 adults from West Virginia took part in this program, which included six cycles of participants and a control group and which lasted from the Fall of 1978 until the Spring of 1981 Further descriptions of both the sample $(N=909)$ and intervention are avalable in greater detall elsewhere [54-56]

Of special relevance here is the extreme heterogeneity of religious expression despite the fact that this region is united by both its industry (coal-mining) and social environment (poverty, severe cyclic unemployment, social isolation, and political neglect) Mainstream religious denominations coexist with a wide array of enthusiastic sects, including a church where the devout obey the scriptural call to 'take up serpents' as a ritual part of worship Religion, while practiced perhaps no more than in other regions, is a constant focus of attention, to the extent that seemingly trivial differences (from an etic perspective), such as the amount of water used in a baptism, become magnified and subjected to heated debate between '10-gallon' and 'half-pint' Baptısts Perhaps because of so few other distinctions in this region, religious variations loom so large This pervasive and continuous attention to rehigion and religious distinctions leads us to surmise that if religious differences in health-care-seekıng are to be documented anywhere, it is here

For this brief analysis, four indices of health care uttlization were used frequency of physician visits ("How frequently do you see a physician", coded $0=$ less than once a year, $1=$ once a year. $2=2$ or 3 tumes a year, $3=46$ times a year, $4=$ once a month. $5=$ more than once a month), length of time since last physician visit and length of time since last hospitalization ("When was the last tıme you saw a physician" and, "When was the last time you were hospitalized"', both coded $1=$ less than 3 months ago, $2=$ between 3 and 6 months ago, $3=$ between 7 months and a year ago, $4=$ between 1 and 15 years ago, $5=$ between 15 and 2 years ago, $6=$ more than 2 years ago), and length of stay during last hospltalization ("How many days were you in the hospital"') Four measures of religion were used, allowing us to explore each of the four hypothesized locl at which we suggested religion might conceivably influence utilization These items included church membership ("Do you belong to a church"", coded $0=$ no, $1=$ yes), religıous affiliation ("What is your religious preference?", open-ended, with over a dozen responses collapsed for analytical purposes to Baptıst, Methodist, Presbyterian, Roman Catholic, Epıscopalıan, Mormon, Pentecostal/Holiness, and none), religious attendance ("How frequently do you attend church", coded $0=$ less than once a month or never, $1=$ once a month, $2=$ every other week, $3=$ every week, $4=$ more than once a week), and holding a church office ("Are you an officer of your church", coded $0=$ no, $1=$ ycs)

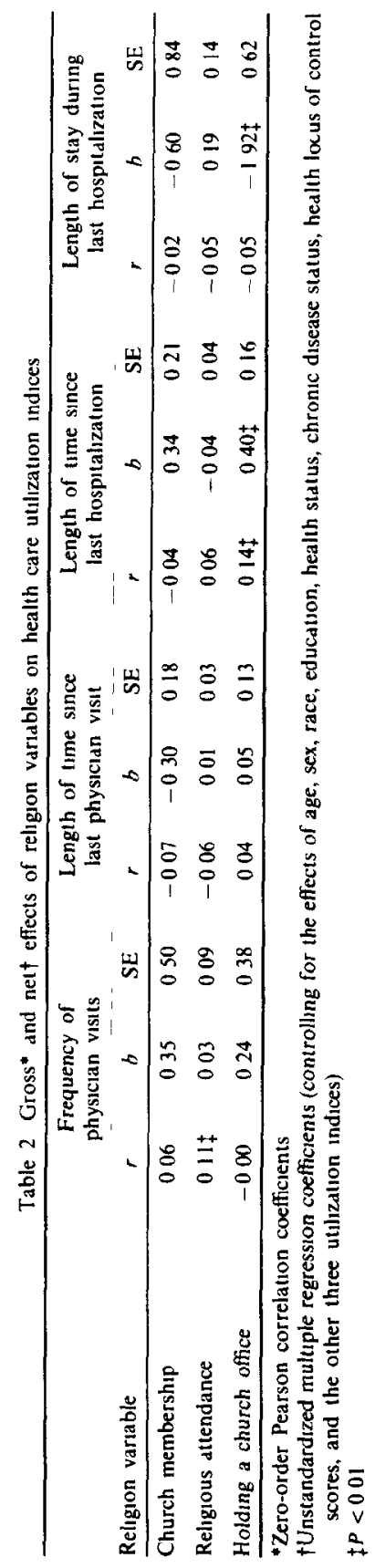


Table 3 ANOVAs of differences in health care utilization indices across categories of religious affiliation

\begin{tabular}{|c|c|c|c|c|c|c|c|c|}
\hline \multirow[b]{2}{*}{ Religious affiliation } & \multicolumn{2}{|c|}{$\begin{array}{l}\text { Frequency of } \\
\text { physician visits }\end{array}$} & \multicolumn{2}{|c|}{$\begin{array}{l}\text { Length of time since } \\
\text { last physicran visit }\end{array}$} & \multicolumn{2}{|c|}{$\begin{array}{l}\text { Length of time since } \\
\text { last hospitalization }\end{array}$} & \multicolumn{2}{|c|}{$\begin{array}{l}\text { Length of stay during } \\
\text { last hospitalization }\end{array}$} \\
\hline & Mean & $n$ & Mean & $n$ & Mean & $n$ & Mean & $n$ \\
\hline $\begin{array}{l}\text { Baptist } \\
\text { Methodist } \\
\text { Presbyterian } \\
\text { Roman Catholic } \\
\text { Episcopalian } \\
\text { Mormon } \\
\text { Pentecostal/Holıness } \\
\text { None }\end{array}$ & $\begin{array}{ll}2 & 83 \\
2 & 65 \\
1 & 37 \\
1 & 55 \\
1 & 15 \\
2 & 04 \\
3 & 34 \\
0 & 69\end{array}$ & $\begin{array}{r}306 \\
132 \\
19 \\
31 \\
13 \\
27 \\
148 \\
13\end{array}$ & $\begin{array}{ll}2 & 41 \\
2 & 50 \\
1 & 83 \\
2 & 56 \\
1 & 85 \\
2 & 33 \\
2 & 33 \\
2 & 92\end{array}$ & $\begin{array}{r}285 \\
131 \\
18 \\
27 \\
13 \\
27 \\
145 \\
13\end{array}$ & $\begin{array}{l}465 \\
478 \\
505 \\
493 \\
492 \\
419 \\
449 \\
362\end{array}$ & $\begin{array}{r}282 \\
127 \\
19 \\
30 \\
13 \\
26 \\
142 \\
13\end{array}$ & $\begin{array}{l}943 \\
633 \\
458 \\
548 \\
523 \\
533 \\
609 \\
350\end{array}$ & $\begin{array}{r}268 \\
122 \\
19 \\
29 \\
13 \\
21 \\
128 \\
10\end{array}$ \\
\hline $\begin{array}{l}\text { Grand mean } \\
\text { SD } \\
N \\
F\end{array}$ & $\begin{array}{c}270 \\
439 \\
689 \\
176\end{array}$ & & $\begin{array}{c}240 \\
160 \\
659 \\
091\end{array}$ & & $\begin{array}{r}463 \\
196 \\
652 \\
117\end{array}$ & & $\begin{array}{r}744 \\
1151 \\
610 \\
218^{*}\end{array}$ & \\
\hline
\end{tabular}

Analyses were conducted in two parts First, we tested for significant religious effects on the utilization of health care by regressing each of the four utılization indices onto church membership, relıgıous attendance, and holding a church office Using listwise deletion of missing values, the effects of several 'predisposing' and 'need' variables were controlled These included age, sex, race, and education, along with health status, chronic disease status, the other three utilization indices, and scores on the multidimensional health locus of control (MHLC) scales [57] The MHLC has been significantly related to both health and religion in this sample [58] Second. we tested for significant differences in utilization across denominations by conducting ANOVAs on the denomination means of each of the utilization indices Both sets of analyses were conducted in SAS. and results are shown in Tables 2 and 3

In Table 2, both gross and net effects of religion on utilization are presented There were two significant zero-order correlations the frequency of religious attendance was related to the frequency of physician utilization, and holding a church office was associated with a lengthy duration since the previous hosp1talization At the net level, the religious attendance finding is explained away, the church office finding remains, and an inverse suppressor effect is uncovered for holding a church office on the length of stay during the last hospitalization In sum, neither belonging to nor attending church appear to have a net effect on physician or hospital utilization Furthermore, the salutary effects for holding a church office might derive from a sort of selection bias, in that perhaps only the sturdiest and most energetic congregants become deacons, elders ushers, etc

In Table 3, only for length of stay during last hospitalization was there a significant difference in means across denominations Baptists had the longest stays and the unaffiliated had the briefest While religious differences in the other three utilization indices were not significant, this may be due in part to the small number of subjects in some denom1nations coupled with large standard deviations Nonetheless, there does appear to be some denominational variation in the means of these indices For example, members of higher-socioeconomic-status (SES) denominations (Presbyterians, Epıscopalians, Roman Catholics) seem be have had fewer physician visits than members of lower-SES denominations and sects (Baptists, Pentecostal/Holiness adherents) However, it is uncertain whether these results are attributable to any intrinsically meanıngful effect related to a religıous personality-type or ethos, since physician utilization is known to vary inversely with SES [59] Indeed, controlling for education and age reduced the finding for length of stay during last hospitalization to insignificance (not shown in table)

In sum, while several significant relıgıous differences have been revealed, once again they do not add up to convincing evidence of a consistent, generalizable trend Furthermore, even where significant findings are found, it appears that they may be explainable by social or demographic factors and that a consistent psychosocial or psychodynamic effect of religion on utilization-much less some sort of residual superempirical or 'supernatural' influence-1s not suggested by these data

\section{CONCLUSIONS}

The results of the literature review coupled with the additional findings presented here are paradoxical, to say the least On the one hand, the literature seems to show clearly that patterns of health care utilization vary by religion, a finding supported to some extent by data from Appalachia which show several significant religious effects On the other hand, as discussed, there is some reason to believe that these findings may be spurious (although it is impossible to say with certainty), and, regardless, religion and the use of health care do not appear from these and previously published data to be related in a meaningfully patterned way

Nevertheless, despite the absence of a theoretically coherent trend in these admittedly limited data, the apparently unpatterned denominational differences found in the use of health care may be of considerable significance to public health educators, planners, and administrators, if not to health services researchers That is, even if religious orientation does not directly determine the use of health care, it may still be a critical factor insofar as it contributes to the willingness of individuals to engage in certain healthrelated practices (e $\mathrm{g}$ self-care, hygienic regimens) or hold certain health-related beliefs or attitudes which 
are causally antecedent to utilization In other words, the Kosher diet of Orthodox Jews, the Lebensstul of Mormons and Seventh-day Adventists, the history of mutual and and self-help among Black Baptists and Methodists, and every other disposition concerning preventıve practices, attitudes toward physicians and health care, reactions to pain, and behefs about the relation of body to Spirit-dispositions which vary by religious affiliation [60]-may all provide avenues by which religion exerts indirect effects on utilization, whether preventive, curative, or pallıatıve

Another important consideration in this line of research involves the ideological assumptions underlyıng a search for determinants of health care utılization in intrapsychic factors such as an individualistically-defined 'religion' instead of in extrinsic, socioenvironmental factors- e g those outlined in Penchansky and Thomas' [61] mult1dimensional operationalization of access Ironically, these latter types of determinants could reasonably include collectively experienced, more structurally defined religious barriers or enablers which, because they are not psychologistically defined as traits, are not 'seen' by researchers and thus not investigated [62] In most studies of health care use in which analyses are conducted according to Andersen's [63] paradigmatic bchavioral model, 'predisposing' factors (such as individual religiosity) are found to contribute very little to explanations of variance relative to 'need' (health-related) factors and characteristics of the prevalling health care system Therefore, should the nature of the relationship between health care use and individual religious orientation and expression finally be clarified, health services research may have advanced only a short distance toward understanding why people do and do not utllize health care

Perhaps, however, this is too critical a stance After all, as shown, religion, as conceptualized in health services research-despite its poor operational engagement and its overall explanatory weaknessdoes seem to be a significant, if only semi-consistent predictor of health care utilization This paradoxical set of considerations leads to two general and somewhat opposing recommendations

First, from the standpoint of efforts seeking a meaningful understanding of the relation(s) between religion and the use of health care, the sole use of conceptually unsophisticated indicators of an undefined 'religıousness', such as religious attendance and trichotomous affiliation measures, is a less than fruitful practice that should probably be terminated That is not to say that these are not useful measures, they are Rather, they should not be expected to represent content-valid indicators lapping the full range of the concept of religion If health services researchers choose not to pursue more sophistıcated analyses of religious effects, than perhaps the study of religious factors in the use of health care should be discontinued

Second, the state of this line of research very much resembles the epidemiologic and gerontological literatures on religion of several years ago unreviewed, unsynthesized, operationally unsophisticated, devold of theoretical direction-in short, going nowhere However, once multıple and multidimensional re- ligion indicators began to be employed and once theoretical development [64] and hypothesis-testing [50] began in earnest, important conclusions began to be reached [3], theoretical models were developed [53], and new directions for research unfolded For these reasons, should the effects of religion be deemed worthy of further investigation, then health services researchers should realize that there are many useful measures of religion that can be employed for their purposes The sociology and psychology of religion are replete with psychometrically-vahdated scales which tap a myriad of religious dimensions [65-67], two cases in point being the semınal five-dimensional scale of Glock and Stark [68] and its subsequent adaptations [69], and the scales [70,71] derived from Allport's [72] two-part definition of religiosity Such measures are undoubtedly of greater value than the 'default' measures of affiliation and attendance which may largely represent proxies for SES and functional health [73-75], respectively

In short, if health services researchers are indeed interested in uncovering meaningful, independent religious effects, then the conventional, uninformed way of treating this issue must change, there is little reason to believe that the effects of religion-however defined or measured-have been satisfactorily investigated in this field This characterization may seem unduly harsh, but it is not clear that dozens of additional studies providing zero-order comparisons of, say, the frequency of private dental visits between Jews and Gentıles will represent much of a substantive contribution either to the study of religion and health or, more importantly, to health services research

Finally, as much as empirical researchers like to avoid such things, the search for consistent religious factors in health care use must not occur in a theoretical vacuum In particular, two questions must initially be asked First, should there actually be any relationship between religion and the use of health care? This is not the difficult question, most scholars writing in this area from the sociomedical sciences $[2,51]$ and religion [76] would say, "Yes" Therefore, the next step should be the development and testing of relevant theoretical models An example is provided in Fig l This model's substantive content is not at issue here, and so will not be discussed further Rather, the positıng of such a model exemplies, in a simple form, just what is now required of researchers in this area

Second, and more to the point, assuming religion and health care use can be related theoretically, is this relationship necessarily a salutary one? That 1 , must higher levels of religiosity necessarily be associated with higher levels of preventive care utilization and lower rates of hospitalization? Is it not untrue to the major religious traditions to assume that (a) 'religion' is a singular, monolithic, unidimensional entity, and (b) it necessarily has a positive influence on health? Alongside of religiously dictated codes of hygiene, there exist attitudes which view disease as purificatory and suffering as sacrificial Religious experience in both the West and East is replete with examples of how the tension between Spirit and flesh is often resolved by renouncing the latter for the sake of the former Only rarely, it seems, do scientists 


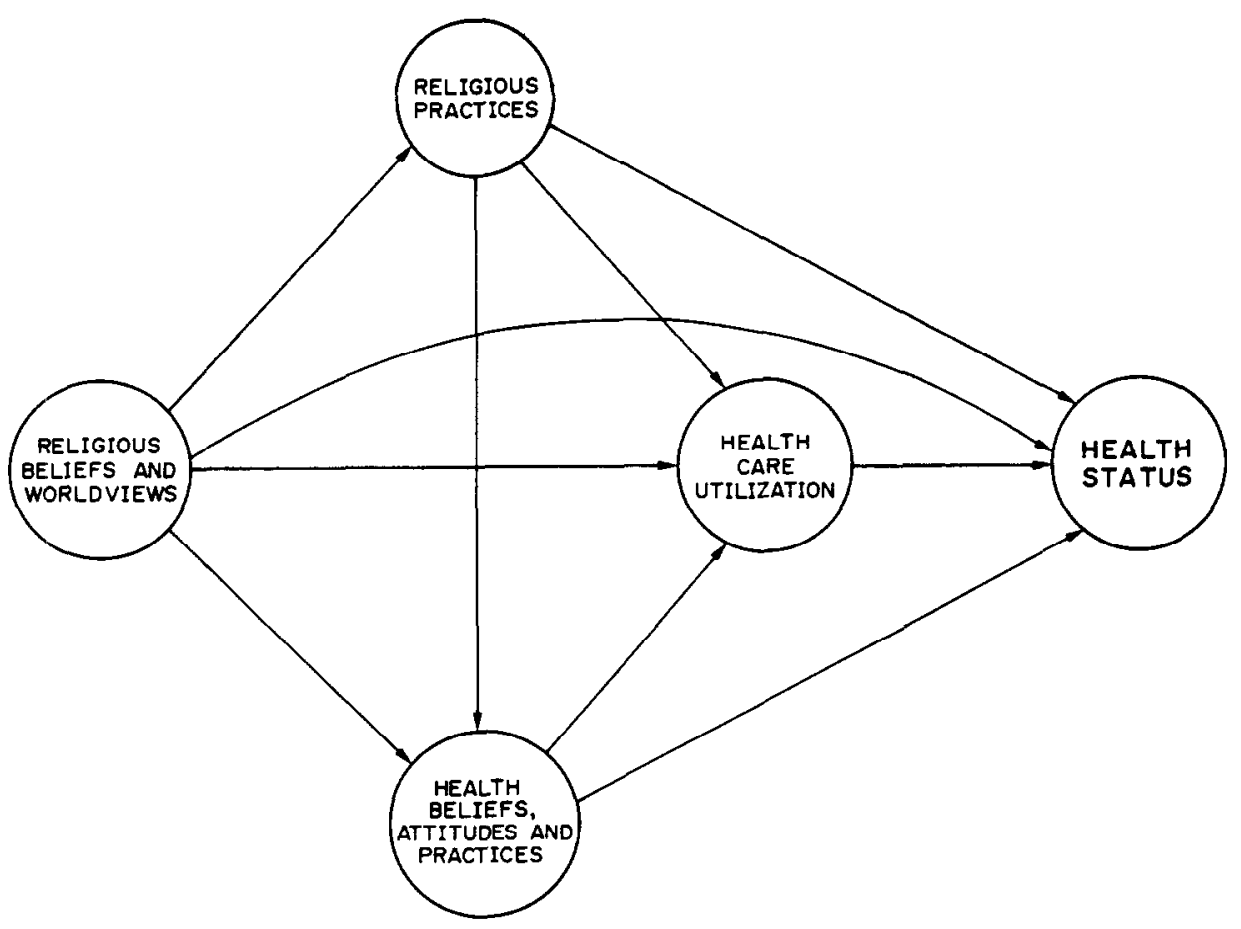

Fig 1 A simple, fully recursıve model relating religious factors to health care and health

ponder the possibly deleterious effects of religion upon health [77] Most likely, some aspects of religion are salutary and keep rates of health care use down (or, in some instances, up), while other aspects of religion are harmful and thus elevate utilization (or. in some cases, depress it) Furthermore, this phenomenon likely varies by religious affiliation [78] In answer, then, to the question, "Is there a religious factor in health care utilization?," one must reply with an unqualified, "Sort of "If this area of health services research is to be advanced, then clearly much prelımınary work remains to be done

Acknowledgements - The authors wish to acknowledge Julia Thomas and Dr Allen Steckler of the University of North Carolina School of Public Health for their help with computer programming and data analysis, John Bryl of the University of Michigan for his assistance with computer graphics, and, the comments of an anonymous reviewer

\section{REFERENCES}

I Levin J $S$ and Schiller $P$ L Is there a religious factor in health? $J$ Relig Hith 26, 9-36, 1987

2 Levin J S and Vanderpool H Y Is frequent rehgious attendance really conducive to better health' toward an epidemıology of relıgion Soc Sct Med 24, 589-600, 1987

3 Bergin A E Religiosity and mental health a critucal reevaluation and meta-analysis Prof Psychol 14, 170-184, 1983

4 Larson D B, Pattison E M, Blazer D G, Omran A $\mathrm{R}$ and Kaplan $\mathrm{B} H$ The measurement of religion in psychiatric research In Psychiatry and Religion Overlapping Concerns (Edited by Robinson $\mathrm{L} H$ ), pp 156-178 American Psychıatry Press, Washıngton, D C, 1986

5 Levin J S Religious factors in aging, adjustment, and health a theoretical overview $J$ Relig Aging In press
6 Witter R A, Stock W A, Okun M A and Haring $H$ J Religion and subjective well-being in adulthood a quantutative synthesis Rev Relig Res 26, 332-342, 1985

7 Andersen $R$ and Newman $J$ Societal and individual determınants of medical care utılızation Milbank $\mathrm{Meml}$ Fund $Q$ 51, 95-124, 1973

8 Mechanic D Public Expectantons and Health Care Essays on the Changing Organization of Health Services, pp 206-208 Wiley, New York, 1972

9 Donabedian A Aspects of Medical Care Administratıon, pp 422-425 Harvard University Press, Cambridge, Mass, 1973

10 Morrill R L and Eanckson R Hosputal Service Areas, Parts I-IV Working Papers I 3, I 4, I 5, and I 6 Chicago Regional Hospital Study, Chicago, Ill, 1968

11 Mornil R L and Earickson R Influence of Race, Religion and Ability to Pay on Patıent to Hospital Distance Workıng Paper I 17 Chicago Regional Hospital Study, Chicago, Ill , 1968

12 Kaplan S Report on Jewish Births and Jewish Population in Cook County, Illinots, 1963 Jewısh Federation of Metropolitan Chicago, Chicago, III, 1966

13 Natıonal Opınıon Research Center National Data Program for the Soctal Sciences Codebook for the Spring 1972 General Social Survey University of Chicago Press, Chicago, Ill, 1972

14 Maurana $\mathrm{C}$ A. Eichhorn $\mathrm{R} L$ and Lonnquist $\mathrm{L}$ E The Use of Health Services Indices and Correlates, $A$ Research Bibliography, 1981 NCHSR Pub No 82-65 Natıonal Center for Health Services Research, Rockville, Md, 1982

15 Byrne J $T$ and Price J H In sickness and in health the effects of religion Hlih Ed Jan./Feb., 6-10, 1979

16 Abernathy W J and Moore J R Regional planning of primary health care services Med Care 10, 380-394, 1972

17 Moroney R M and Kurtz N Extended care benefits a comparison of utilization of two age groups Inquiry $10,50-53,1973$ 
18 Johnson A L, Jenkıns C D, Patrıck R and Northcutt $\mathrm{T} \mathrm{J} \mathrm{Jr}$ Epidemology of Pollo Vaccine Acceptance Florida State Board of Health, Monograph No 3, 1962

19 Schonfield J, Schmıdt W M and Sternfeld L Medical attitudes and practices of parents toward a mass tuberculin testing program Am $J$ publ Hlth 53, 772-781 1963

20 Yeracaris C Social factors associated with the acceptance of medical innovations a pilot study $J$ Hlth Human Behav 3, 193-198, 1962

21 Srole $\mathrm{L}$ and Langner $\mathrm{T}$ Religious origin In Menta Health in the Metropols The Midiown Manhattan Study (Edited by Srole L, Langner T S, Michael S T Opler M K and Rennie T A C), pp 300-324 McGraw-Hill, New York, 1962

22 Segal B Emotional adjustment, social organization and psychratric treatment rates $A m$ Soc Ret 30, 548-556. 1965

23 Scheff T J Users and non-users of a student psychiatric clinic $J$ Hith Human Behan 7, 114-121, 1966

24 Linn L Social characteristics and social interaction in the utilization of a psychiatric outpatient clinic $J$ Hith soc Behav 8, 3-14, 1967

25 Cauffman J G, Peterson E L and Emrick J A Medical care of school children factors influencing outcome of a referral from a school health program Am $J$ publ Hith 57, 60-73, 1967

26 Horwitz S M, Morgenstern $\mathrm{H}$ and Berkman $\mathrm{L}$ The impact of social stressors and social networks on ped atric medical care use Med Care 23, 946-959, 1985

27 Tessler $\mathbf{R}$ and Mechanic D Factors affectıng children's use of physician services in a prepaid group practice Med Care 16, 33-46, 1978

28 Notzon $\mathbf{R}$ Utilization of family planning services by currently married women 15-44 years of age. United States, 1973 Vital Hlth Statis 23(1), 1-36, 1977

29 Collver A, Ten Have $R$ and Speare M C Factors influencing the use of maternal health services $S o c S_{c i}$ Med 1, 293-308, 1967

30 Fink $R$, Shapiro $S$ and Lewison $J$ The reluctant participant in breast cancer screening programs Publ Hlth Rep 83, 479-490, 1968

31 Schaefer E J and Hughes J R Socioeconomic factors and maternal and child heaith care Med Care 14, $535-543,1976$

32 Wan T T H and Yates A S Prediction of dental services utilization a multıvariate approach Inquirv 12 , 143-156, 1975

33 Bashshur $R$ L, Shannon $G W$ and Metzner $C A$ Some ecological differentials in the use of medical services Hith Sert Res 6, 61-75, 1971

34 Andersen R Health services distribution and equity In Equity in Health Services Empirical Analvses in Social Policy (Edited by Andersen $\mathbf{R}$, Kravits $\mathbf{J}$ and Anderson O W ), pp 9-32 Ballınger Cambridge, Mass, 1975

35 Morrill R L, Earickson R J and Rees P Factors influencing distances travelled to hospitals Econ Geogr 46, $161-171,1970$

36 Morrill R L and Earickson R Locational efficiency of Chicago hospitals an experimental model Hlth Sert Res 4, 128-141, 1969

37 Levenson I Access to medical care the Queensbridge experience Inquiry 9, 61-68, 1972

38 Solon J A Patterns of medical care sociological variations among a hospital's outpatients $A m J$ publ Hith 56, 884-894, 1966

39 Stratmann W C A study of consumer attitudes about health care the delivery of ambulatory services Med Care 13, 537-548, 1975

40 Tessler R, Mechanic $D$ and Dimond $M$ The effect of psychological distress on physician utilization a prospective study $J$ Hlth soc Behat 17, 353-364, 1976

41 Nnadi E $F$ and Kabat H F Nigerians' use of native and Western medicine for the same illness Publ Hlth Rep 99, 93-98, 1984

42 Wan T T H and Solfer S J Determinants of physician utilization a causal analysis $J$ Hlth soc Behat 15 $100-108,1974$

43 Levin J S and Markides $\mathrm{K}$ S Religion and health in Mexican Americans $J$ Relig Hlth 24, 60-69, 1985

44 Greenlick M R, Hurtado A V, Pope C R, Saward E W and Yoshroka S S Determinants of medical care utulization Hlth Seri Res 3, 296-315, 1968

45 Weiss G L. The influence of need and care and selected sociodemographic characteristics on the utilization of physician services Unpublished M S thesis, Department of Sociology, Purdue University, Lafayette. Ind , 1972

46 Slesinger D P, Tessler R C and Mechanic D The effects of social characteristics on the utilization of preventive medical services in contrasting health care programs Med Care 14, 392-404, 1976

47 Roghmann K J The use of medications a neglected aspect of health and iliness behavior In Child Health and the Communit (Edited by Haggerty $\mathrm{R} J$, Roghmann $\mathrm{K} J$ and Kurtz N ) Wiley, New York, 1975

48 Abernathy $W \mathrm{~J}$ and Schrems E L Distance and Health Services Issues of Utlization and Factlth Choice for Demographic Strata Research Paper No 19 Graduate School of Busıness, Stanford University, Palo Alto, Calif, 1971

49 Levin $J$ S and Vanderpool $H$ Y Is religion therapeutically significant for hypertension? Unpublished manuscript

50 Levin J S and Markıdes $\mathbf{K}$ S Rehigious attendance and subjective health $J$ Scl Study Relig 25, 31-40, 1986

51 Zborowskı $M$ Cultural components in responses to pain $J$ Soc Issues 8, 1630,1952

52 Zola I K Culture and symptoms Am Soc Rev 31 $615-630,1966$

53 Jarvis $G \quad K$ and Northcutt $H \quad C$ Religion and differences in morbidity and mortality Soc SCl Med 25, 813-824, 1987

54 Schiller P L, Steckler A and Dawson I, H Health Activation in Coal County, Appalachia In Perspectives on Community Health Education A Series of Case Studies, Volume One Unted States (Edited by Carlaw R W ), pp 47-69 Third Party, Oakland, Calif, 1982 55 Schiller $P$ L, Steckler $A$ and Dawson L Insıder/outsider dilemmas in the development of an Appalachian self-care health education program Int $Q$ Commun Hlth Ed 3, 153-171, 1983

56 Schiller P L, Steckler A, Dawson L $\mathrm{H}$ and Patton F A Parlicipatory Planning in Community Health Education $A$ Guide Based on the McDowell County, West Virginia Experience Third Party Associates, Oakland, Calif, 1987

57 Wallston K, Wallston B and DeVellis R Development of the Multidimensional Health Locus of Contro (MHLC) Scales Hith Ed Monogr 6, 161-170, 1978

58 Levin J S and Schiller P L Religion and the Multidimensional Health Locus of Control Scales Psychiat Rep 59, 26, 1986

59 Andersen R, Lion J and Anderson O W Two Decades of Health Services Social Survey Trends in Use and Expenditure Ballinger, Cambridge, Mass, 1976

60 Numbers R $\mathrm{L}$ and Amundsen D W (Eds) Carmg and Curing Health and Medicine in the Western Religious Traditions Macmillan, New York, 1986

61 Penchansky $R$ and Thomas $J$ W The concept of access definition and relationship to consumer satisfaction Med Care 19, 127-140, 1981

62 Stark R Religion and conformity reaffirming a sociology of religion Soc Anal 45, 273-282, 1984

63 Andersen $\mathbf{R}$ A Behavioral Model of Familes' $U$ se of 
Health Services Research Serres No 25 Center for Health Administration Studies, University of Chicago, Chicago, III , 1968

64 Mindel C $\mathrm{H}$ and Vaughan C E A multıdimensional approach to religiosity and disengagement $J$ Geront 33, 103-108, 1978

65 Robinson J P and Shaver P R Measures of Social Psychological Attitudes, pp 543-635 Institute for Social Research. Ann Arbor, Mich, 1970

66 Dittes J E Two issues in measuring religion In $R e$ search on Religious Development A Comprehensive Handbook (Edited by Strommen M P), pp 78-106 Hawthorn Books, New York, 1971

67 Gorsuch R L Measurement the boon and bane of investigatıng religion Am Psychol 39, 228-236, 1984

68 Glock $C$ Y and Stark $R$ Religion and Society in Tension Rand McNally, Chicago, Ill , 1965

69 Faulkner $J$ E and DeJong $G$ Religiosity in 5-D an empirical analysis Soc Forces 45, 246-254, 1966

70 Kahoe R D The development of intrinsic and extrunsic religious onentations $J$ Sct Study Relig 24, 408-412, 1985
71 Donahue $M J$ Intrnnsic and extrnnsic religiousness the empincal research $J$ Sct Study Relig 24, 418-423, 1985

72 Allport G W The Nature of Prejudice, p 422 Anchor Books, New York, 1958

73 Steinitz L Y Religiosity, well-being, and Weltanschauung among the elderly $J S_{c t}$ Study Relig 19, $60-67,1980$

74 Comstock G W and Tonascia J A Education and mortality in Washington County, Maryland $J$ Hlth soc Behav 18, 54-61, 1977

75 Levin J S and Markıdes K S Relıgıous attendance and psychological well-being in middle-aged and older Mexican Americans Soc Anal 49, 66-72, 1988

76 Vaux K Religion and health Prev Med 5, 522-536, 1976

77 Kaplan B H A note on religious beliefs and coronary heart disease JS Carolina med Ass suppl, 60-64, February 1976

78 Spector R E Cultural Diversity in Health and Illness, pp 114-123 Appleton-Century-Crofts, New York. 1979 